\title{
Integrated Community Program to Strengthen Subsea Cable Security and Environmental Sustainability in the Offshore Oil and Gas Industry
}

\author{
Harriman Samuel Saragih \\ Business School - Management Department \\ Universitas Pelita Harapan \\ Tangerang, Indonesia \\ harriman.saragih@uph.edu
}

\begin{abstract}
Offshore oil and gas industry operates daily with the maritime facilities supported by subsea cable. Disruptions or damages to the subsea cable can inevitably stop the production processes. In the recent years, the Company is facing multiple challenges in its relatively large operations area of $8.000 \mathrm{~m} 2$, including subsea cable thievery which have occurred for more than three times in a single year. Proposed approach in implementing CSR to reinforce security system through community empowerment is then formulated, which is different with the previous method. Three-month observable result shows significant improvement to the Company and local community. This proposed denotes further research agenda and implementation to show its effectiveness in managing security, CSR, as well as environmental sustainability amongst oil and gas offshore Companies.
\end{abstract}

Keywords - community development; subsea cable; submarine cable; security; energy; sustainability

\section{I.INTRODUCTION}

Subsea cable or submarine cable is used to distribute electricity and networking tools mainly utilized for industries such as energy and telecommunication. Referring to one case in Riau, Indonesia, the fiber optic's economic value was IDR 600 million per 15 tons [1]. Another case in Indonesia which occurred in Kelapa Island is electricity jam for several hours due to the thievery of subsea cable, managed by the State Electricity Company [2]. Indosat as one of the telecommunication firm in Indonesia, also have previous case records in subsea cable thievery [3]. Figure 1 shows the suspected stolen subsea cables in Belitung, Indonesia.

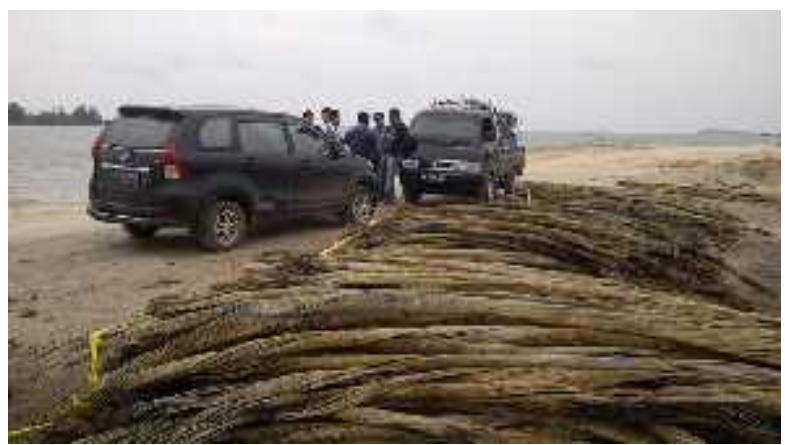

Fig. 1. Suspected Stolen Subsea Cables in Belitung [4]
The object of this research study is one of the largest Asia's Multinational oil and gas producer in the world, CNOOC SES Ltd. In Indonesia, the Company operates daily drilling operations in the Kepulauan Seribu area. Geographically, the Kepulauan Seribu area is located on the south east Sumatera and the northern part Jakarta. Kepulauan Seribu administratively is located as part of DKI Jakarta Municipality. Most of the local islands are fishermen who depend on the sea situation to conduct their daily activities, low education degree, which provide low income and low opportunity to increase their income, unless aided by external capital / parties. The operation area is illustrated in Figure 2.

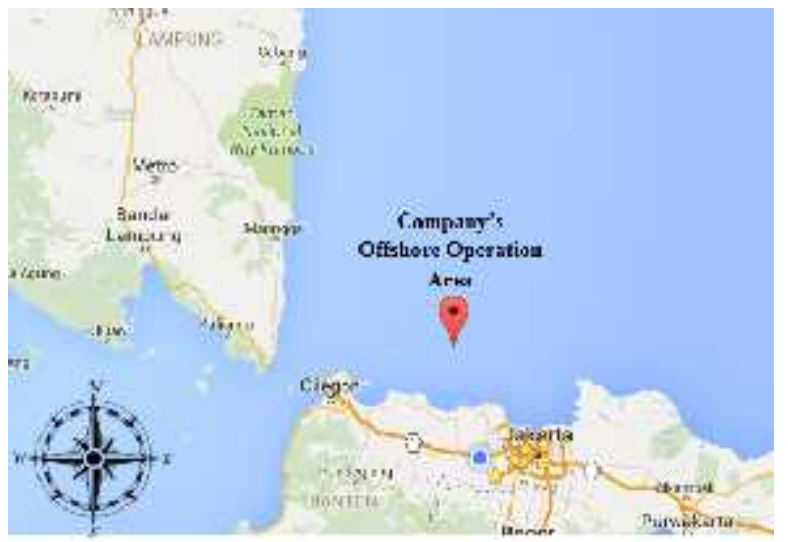

Fig. 2. Company's Operation Area

As an offshore oil and gas producer, the Company relies heavily on the marine facilities that depends on the existence of subsea cable which distributes electric power from central generators, as shown in Figure 3 and Figure 4. Daily production of the Company approximately is 34.000 bopd (Barrel oil per day) while the production target for 2016 is roughly 31.000 bopd. As subsea cable has very important role in supporting these utilities, not only subsea cable has to be maintained, but it also has to be secured from possible damages and more importantly, thievery. The problems arise due to the challenges of securing these assets from local thieves. Subsea cable thievery cases have been increasing from 2013 to 2014 in the Company's surrounding. This has become central issue to the Company as the damage of subsea cable will affect the 


\section{Asuneses PRESS}

operations and will stop production which finally reduce the revenue stream of the Company.

Previous studies or publications that discuss subsea cable security, sustainability, and community empowerment are still lacking. Therefore, this study will contribute insights for oil and gas industries in overcoming security concerns, particularly in subsea cable thievery, and sustainability through community empowerment which is done collaboratively by three departments.

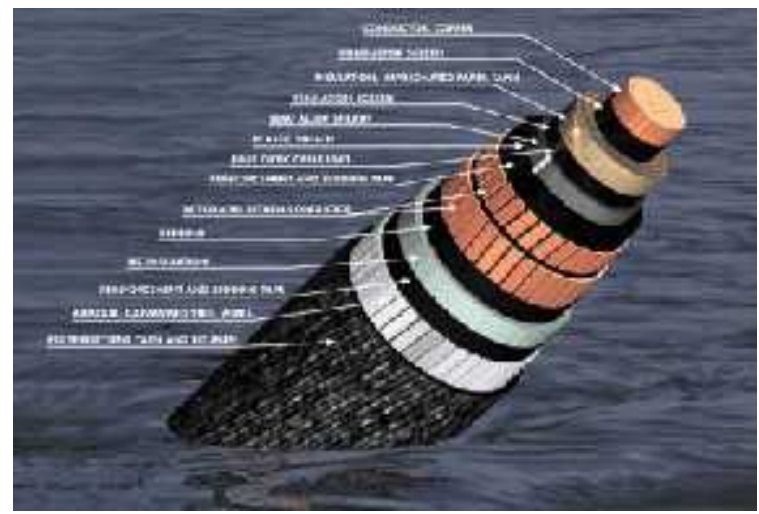

Fig. 3. Illustration of Subsea Cable [5]

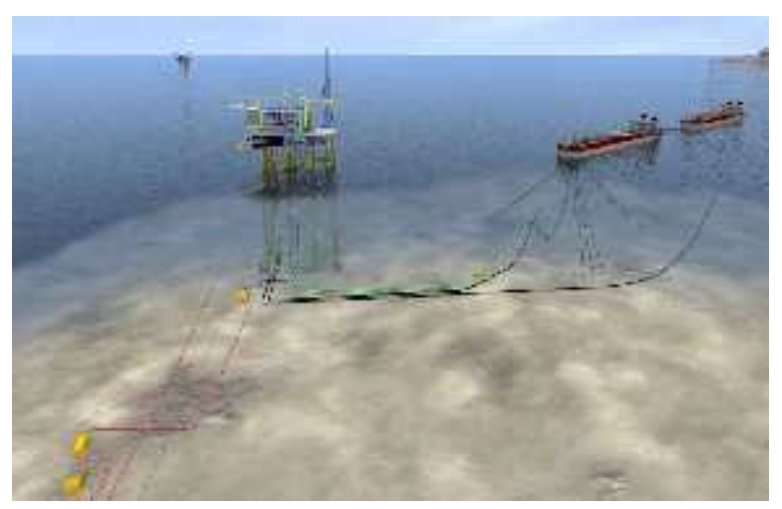

Fig. 4. Subsea Cable Illustration [6]

It is clear that the Company has limited capability to secure the approximately $8.000 \mathrm{~m} 2$ Company's offshore operation area. Security patrol is indeed implemented in day and night to look for suspicious activities, but due to the very large operations area, the Company cannot fully oversee the whole security conditions. The Company found that recent problems of subsea cable thievery are done possibly by the local people which is under economic pressure. Most of the residents in the Kepulauan Seribu are fishermen, which depend on the changing weathers daily. They also generate relatively small income. Exploiting this condition, illegal parties which took advantage the value of subsea cable used effort to this valuable item by stealing this cable illegally and inevitably disrupt the Company's operations. According to the Company's observation, thievery of subsea cable was done through traditional methods. By using regular wooden vessel with electric motor, and customary diving apparatus, the divers assisted by several personnel in the surface brought traditional tools and equipment to cut and took the cable to the surface. Upon completing the actions, the cable is then exchanged with money. The daily operations will be disrupted, and must wait for the new installment of subsea cable.

TABLE I. PERCENTAGE OF POVERTy By REgENCY/MuniciPAlity, 2009-2013 [7]

\begin{tabular}{llllll}
\hline \multicolumn{1}{c}{$\begin{array}{c}\text { Regency / } \\
\text { Municipality }\end{array}$} & \multicolumn{5}{c}{ Percentage of The Poor (Percent) } \\
\cline { 2 - 5 } & $\mathbf{2 0 0 9}$ & $\mathbf{2 0 1 0}$ & $\mathbf{2 0 1 1}^{\text {I) }}$ & $\mathbf{2 0 1 2}^{\text {I) }}$ & $\mathbf{2 0 1 3}^{\text {I) }}$ \\
\hline Kepulauan Seribu & 12.66 & 13.07 & 11.53 & 11.62 & 11.01 \\
South Jakarta & 3.52 & 3.80 & 3.43 & 3.49 & 3.47 \\
East Jakarta & 3.42 & 3.40 & 3.06 & 3.12 & 3.10 \\
Central Jakarta & 3.68 & 3.97 & 3.56 & 3.72 & 3.70 \\
West Jakarta & 3.44 & 3.82 & 3.44 & 3.47 & 3.46 \\
North Jakarta & 5.34 & 5.62 & 5.07 & 5.14 & 5.30 \\
\hline & a. July Condition & b. 1) September Condition &
\end{tabular}

Table 1 illustrates the percentage of poverty in Kepulauan Seribu, and show considerable amount of percentage compared to the Jakarta areas which averaged $3 \%$ to $5 \%$. Kepulauan Seribu shows significant difference in poverty rate which nearly four times the average Jakarta residents. This become a major concern of how can the Company helps to improve the quality of life in Kepulauan Seribu area to support sustainability goal as one of the Company's concern, while on the other hand can be used to assist the Company in securing the subsea cable from illegal thievery in the offshore areas.

TABLE II. LAST EdUCATION DEgREE OF KePUlaUAN SERIBU [7]

\begin{tabular}{|c|c|c|c|c|c|}
\hline \begin{tabular}{l}
\multicolumn{1}{c}{ Last } \\
Education \\
Degree
\end{tabular} & 2009 & 2010 & 2011 & 2012 & 2013 \\
\hline $\begin{array}{l}\text { Can / does not } \\
\text { finish Elementary } \\
\text { School }\end{array}$ & 21 & 14.2 & 24.2 & 25.1 & 17.5 \\
\hline $\begin{array}{l}\text { Elementary } \\
\text { School }\end{array}$ & 41 & 49 & 30.2 & 30.8 & 38.7 \\
\hline $\begin{array}{l}\text { Junior } \\
\text { School }\end{array}$ & 18 & 18.9 & 21.1 & 22.4 & 18 \\
\hline $\begin{array}{l}\text { Senior } \\
\text { School }\end{array}$ & 13 & 14.3 & 19.6 & 17.9 & 19.7 \\
\hline $\begin{array}{l}\text { Academy } \\
\text { University }\end{array}$ & 4 & 3.59 & 4.94 & 3.12 & 6.16 \\
\hline
\end{tabular}

Meanwhile as shown in Table 2, the education quality of Kepulauan Seribu residents are also still low. In 2013 nearly $57 \%$ of the locals are elementary school graduates. This indicates that educational improvement is also needed to improve the quality of life of the residents. This is also in line with the sustainability principles which are people, planet, and profit. This paper will discuss on how the Company has developed new efforts to resolve the security problem in protecting subsea cable, while also involve sustainability plan through community development and finally conceptualize the new managerial framework which is constructed from the proposed approach. 


\section{THEORETICAL FRAMEWORK}

The Company's strategic plan to strengthen the coverage of security systems is to build community-based security. Previously this type of activity has been reported by Saferworld [8]. Reports in the country such as Kosovo, Nepal and Bangladesh have shown substantial tangible results in conducting community-based approach such as improving coordination between national and international security actors; enhancing local governance; improving trust between communities and security providers; redistributing resources to meet community needs; increasing civil society capacity to inform the work of security providers; building trust between social groups; empowering women and improving their experience of safety and security; mobilizing youth to address security issues; and contributing to increased earning potential for poor and marginalized populations [9].

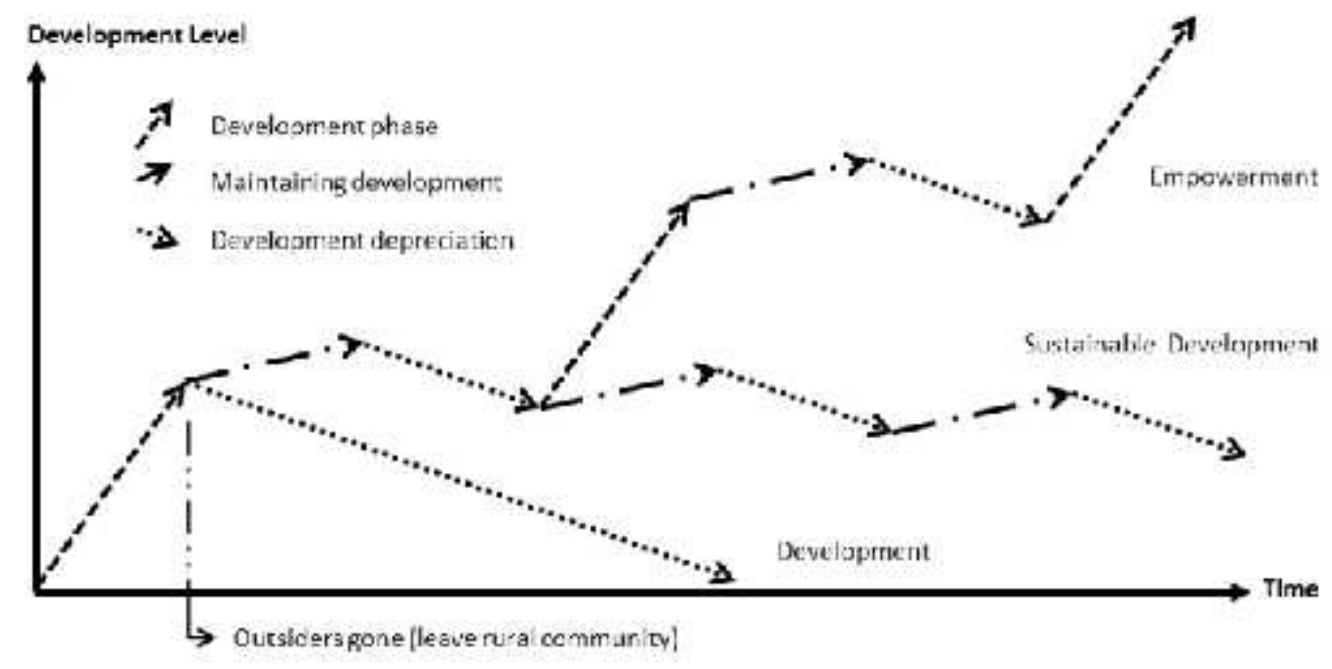

Fig. 5. Comparison between Development, Sustainable Development, and Community Empowerment [10]

According to previous study regarding community development, sustainability and empowerment, Sianipar et al. (2013) illustrates the characteristics of these types of development in a clear figure that also describes contextually the previous CSR conducted the Company. Figure 5 illustrates the idea of community development [10]. The figure shows that in the very basic phase of development, when outsiders finished the particular development project, the development level will gradually decrease through time. In order to answer the main objective of this study, theoretical framework is provided to show the background and focus of the study, as shown in Figure 6. The main problem hypothesized by the Company is the poverty condition which leads to crime rate. This hypothesis is supported by previous studies which resulted positive relationship of poverty and crime rate [11]. In the second phase, the symptoms are clearly defined which shows thievery of subsea cable that disturbs the Company's operation, and also the Company's concern for sustainability. Then discussion and analysis will be carried out to resolve the problems in developing community-based security and sustainable development.

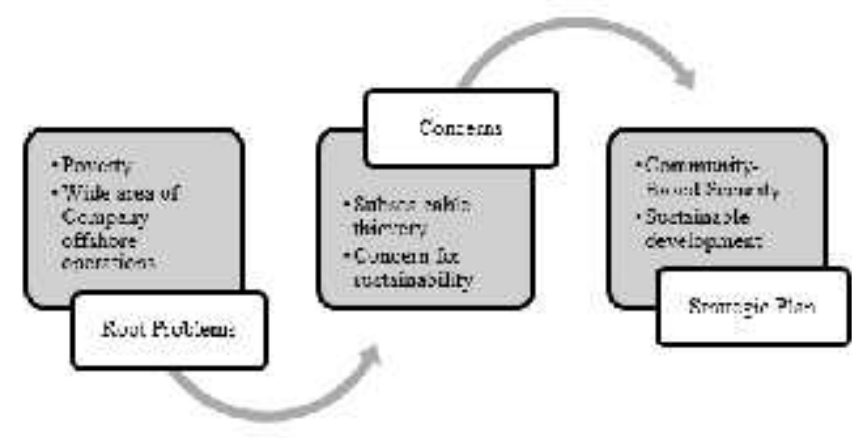

Fig. 6. Theoretical Framework

\section{METHODS}

The study is conducted in the period of 2014 to 2015 and qualitative method is carried out to explore the Company's strategic plan towards sustainability and security concern, particularly in protecting subsea cable. Several techniques such as interview, observation, focus group are done to gather insights from the Company regarding the recent situation and strategic plan to resolve the problems. 
TABLE III.

RESPONDENTS PROFILE

\begin{tabular}{|c|c|c|c|}
\hline $\begin{array}{l}\text { Depart } \\
\text { ment }\end{array}$ & $\begin{array}{r}\text { Total } \\
\text { Personnel }\end{array}$ & Position & Criteria \\
\hline Security & 5 & $\begin{array}{l}\text { Division } \\
\text { Manager, } \\
\text { Department } \\
\text { Head, } \\
\text { Department } \\
\text { Manager, } \\
\text { Department } \\
\text { Officer }\end{array}$ & \multirow[t]{3}{*}{$\begin{array}{l}\text { - More than } 5 \text { years } \\
\text { of experiences in Oil } \\
\text { and Gas Industry } \\
\text { - Experienced in } \\
\text { CSR implementation } \\
\text { in Coastal } \\
\text { Community } \\
\text { - Familiar with the } \\
\text { CSR Concept in } \\
\text { Coastal Community }\end{array}$} \\
\hline QHSE & 3 & $\begin{array}{l}\text { Division } \\
\text { Manager, } \\
\text { Department } \\
\text { Head, } \\
\text { Department } \\
\text { Officer }\end{array}$ & \\
\hline Relations & 2 & $\begin{array}{l}\text { Division } \\
\text { Manager, } \\
\text { Department } \\
\text { Officer }\end{array}$ & \\
\hline
\end{tabular}

Various departments in the Company are taken into account in order to collect comprehensive data and formulation including Security, QHSE (Quality, Health, Safety and Environment), and Relations Department. Profiles of the experts involved in this study is presented on
Table 3. This multiple department discussion is done to reduce information bias and gain different point of view [11]. Collected data is then generated into cross-functional flowchart, both in the previous method and the newly proposed method. Three months after the newly proposed approach had been implemented, several results are documented and evaluated.

\section{RESULT AND DISCUSSION}

Comparisons between previous approaches with the current one is gathered. Previous approach relies only on single department, one-time project and limited budget, while the proposed approach will utilize inter-departments effort to resolve the needs of security and sustainability issue.

Figure 7 shows the previous approach in conducting community development project. First, local community coordinate with the Company which is taken care by Relations Department. Relations then review and evaluate the proposal, and submit to Management for review. If the Management approves, then it will be continued by Relations, if it is not then it will be rejected. The community development plan is then conducted as planned and will be ended if the activity process is completely carried out.

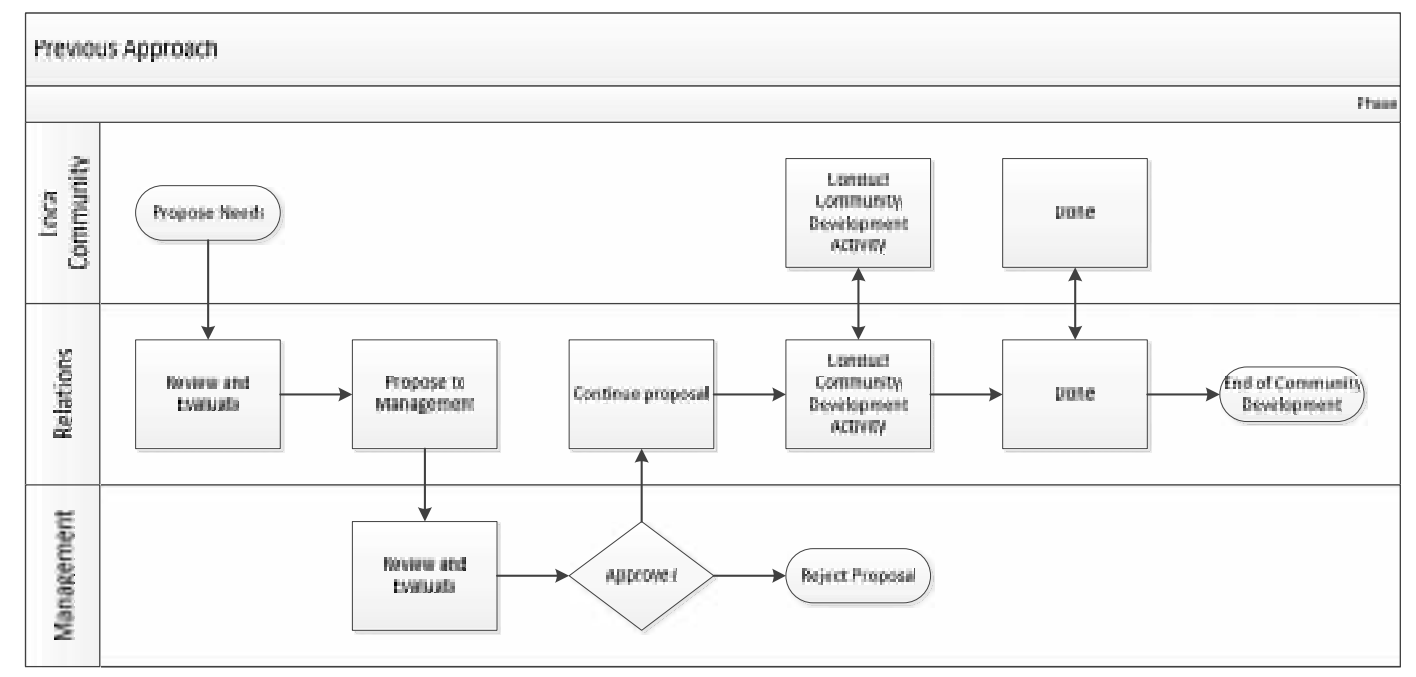

Fig. 7. Previous Approach in Conducting Community Development

According to the interview, activities carried out in the community development project is capital donation. Donation is based on a one-time activity, and does not aim for continuous development. On this study, continuous development is proposed, in line with the study conducted by Sianipar [10] which is intended towards sustainable development and community empowerment. According to previous experiences, Table 4 summarizes the gap between donations as a one-time project with continuous development.
TABLE IV. DIFFERENCE ON DONATION AND CONTINUOUS DEVELOPMENT

\begin{tabular}{|c|c|}
\hline $\begin{array}{l}\text { Donation / One-Time } \\
\text { Project }\end{array}$ & Continuous Development \\
\hline 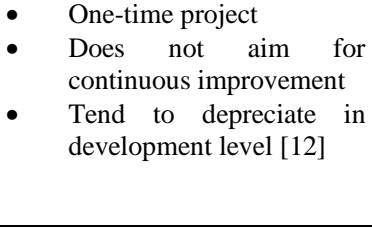 & $\begin{array}{l}\text { - Continuous monitoring and } \\
\text { evaluation } \\
\text { Aim for continuous } \\
\text { improvement in the targeted } \\
\text { community } \\
\text { Tend to increase in } \\
\text { development level [12] }\end{array}$ \\
\hline
\end{tabular}




\section{$\triangle$ ATLANTIS \\ PRESS}

As there is a need from Security Department to empower the local community in assisting the Company to protect the Company's asset, community development program is then engineered to support this purpose. Table 5 summarized the previous approach carried out by the Company in conducting the CSR and the proposed approach. It can be seen that the previous approach is focusing on single-department, lowerbudget, one-time activity for the community development activities, while the proposed approach will use integrated planning, more budget and continuous development.

TABLE V. DIFFERENCE ON PREVIOUS AND PROPOSED APPROACH

\begin{tabular}{|c|c|c|}
\hline Category & $\begin{array}{l}\text { Previous } \\
\text { Approach }\end{array}$ & $\begin{array}{c}\text { Proposed } \\
\text { Approach }\end{array}$ \\
\hline Budget & $\begin{array}{l}\text { By Relations } \\
\text { Department } \\
\text { - Relatively low } \\
\text { budget }\end{array}$ & $\begin{array}{l}\text { - Integrated, Inter- } \\
\text { Department } \\
\text { Budget } \\
\text { - Budget is } \\
\text { increased for the } \\
\text { Community } \\
\text { Development } \\
\text { Project }\end{array}$ \\
\hline
\end{tabular}

\begin{tabular}{|l|l|l|}
\hline (Table V, Cont.) & \multicolumn{2}{|l|}{} \\
\hline Implementation & $\begin{array}{l}\text { Single } \\
\text { Department }\end{array}$ & $\begin{array}{l}\text { J Jointly conducted } \\
\text { - Inter-Department }\end{array}$ \\
\hline Type & $\begin{array}{l}\text { - One-time } \\
\text { project }\end{array}$ & $\begin{array}{l}\text { - Continuous } \\
\text { Monitoring and } \\
\text { Development }\end{array}$ \\
\hline
\end{tabular}

Figure 8 shows the process of the proposed approach. Three concerns are taken into account in the planning phase which are security, relations and QHSE. Main concern from security is how to develop the local community to assist them protecting the Company's asset. QHSE's concern is to ensure that every activity carried out by the Company is environmentally safe, while Relations shall be responsible to maintain good relationship with the local community. These three departments will be the pillars in implementing integrated community development project to support the security and sustainability goal.

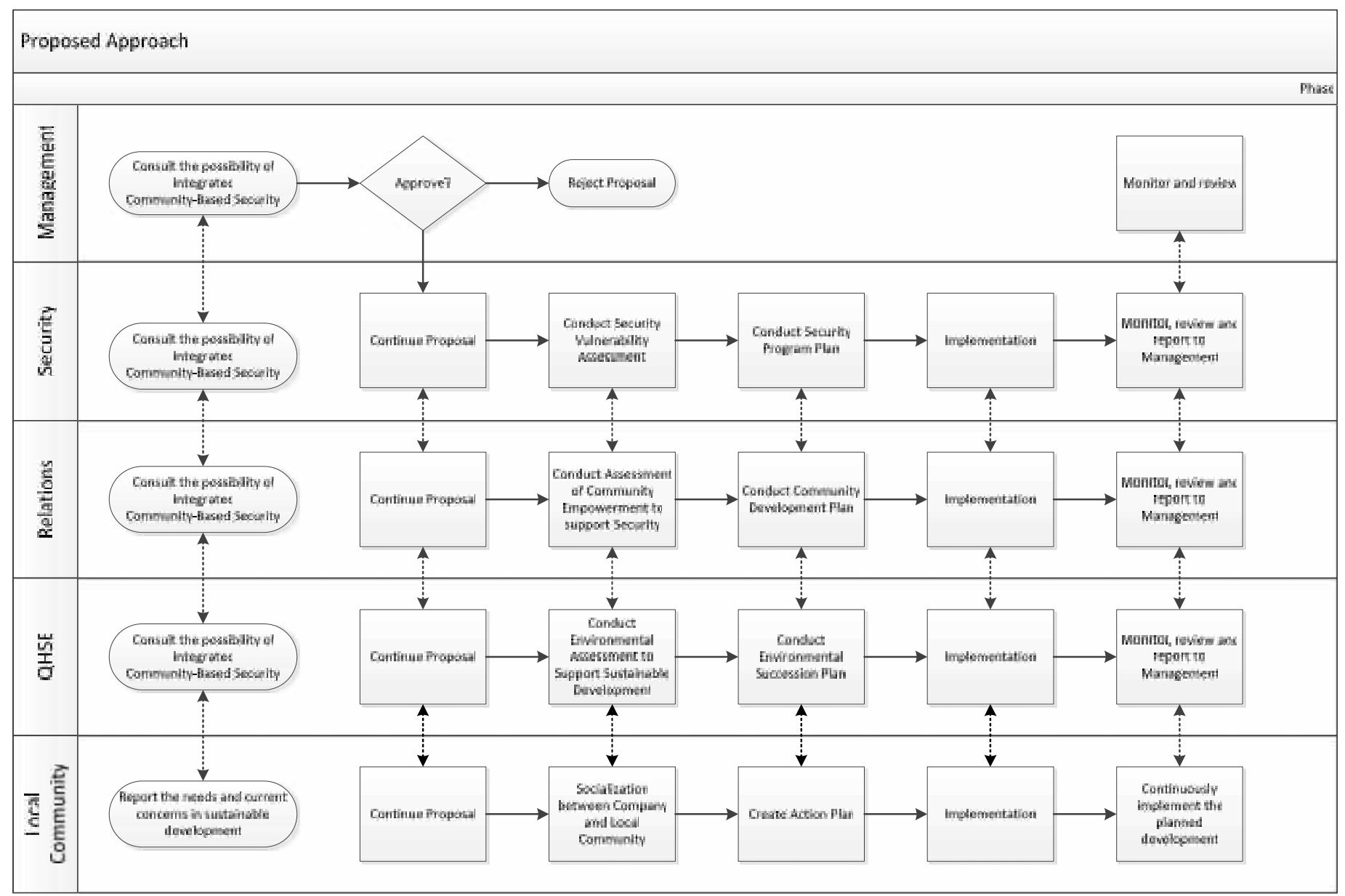

Fig. 8. Integrated Community Development Program

The proposed approach was then implemented to see the result with regard to the concern of, primarily, Company's security and sustainability. Upon the implementation of this integrated Com-dev program, improvement in the field of 
security is seen. The 3-months observable result seen in this proposed approach are improvement in the early detection of suspicious actions by fishermen by local community, improved coordination between local community and Company's security personnel, better relationship between the Company and the local community, and continuous monitoring conducted by both the Company and the local community. In just 3-months, the early detection can successfully catch the perpetrators. This success can lead to wider areas in pursuing the mafia who are conducting the illegal subsea cable thievery.

In terms of the concern for people, relational approach carried out by Relations Department and Security Department has been implemented. Result of the regular meeting and discussion has helped the Company's to understand the issue in the field regarding the needs of the local community, and their concern for mutual symbiosis with the Company. On this particular occasion, the local communities are willing to assist the Company, but they also demand the Company to support the local communities through sustainable development. Hence, with the geographical maritime area and the main profession of most locals which are fishermen, environmental engineering to help these fishermen gather more fishes would be the best alternative to support them. This particular issue would be discussed more on the Environment section. Generally, the local communities fully support the newly proposed approach but mutual cooperation is expected.

Development for better quality of life can still be expanded, to reduce poverty rate and increase the quality of education. Several alternatives are benchmarked and offered to support the sustainability goal of the company. The author argues that educational infrastructure shall be developed in order to support and improve the quality of education of the local community as previously conducted by PHE ONWJ [13]. This is also supported by the current condition of schools which some of them are in poor conditions in the Kepulauan Seribu area such as in Tidung Island [14] and [15]. As education can improve the quality of life, Company shall be actively involved in the development of the people in its daily operations for a better life for local communities. This will also help to socialize to the local communities regarding the consequences of illegal thievery, which is expected to minimize this illegal actions carried out by the future possible perpetrators.

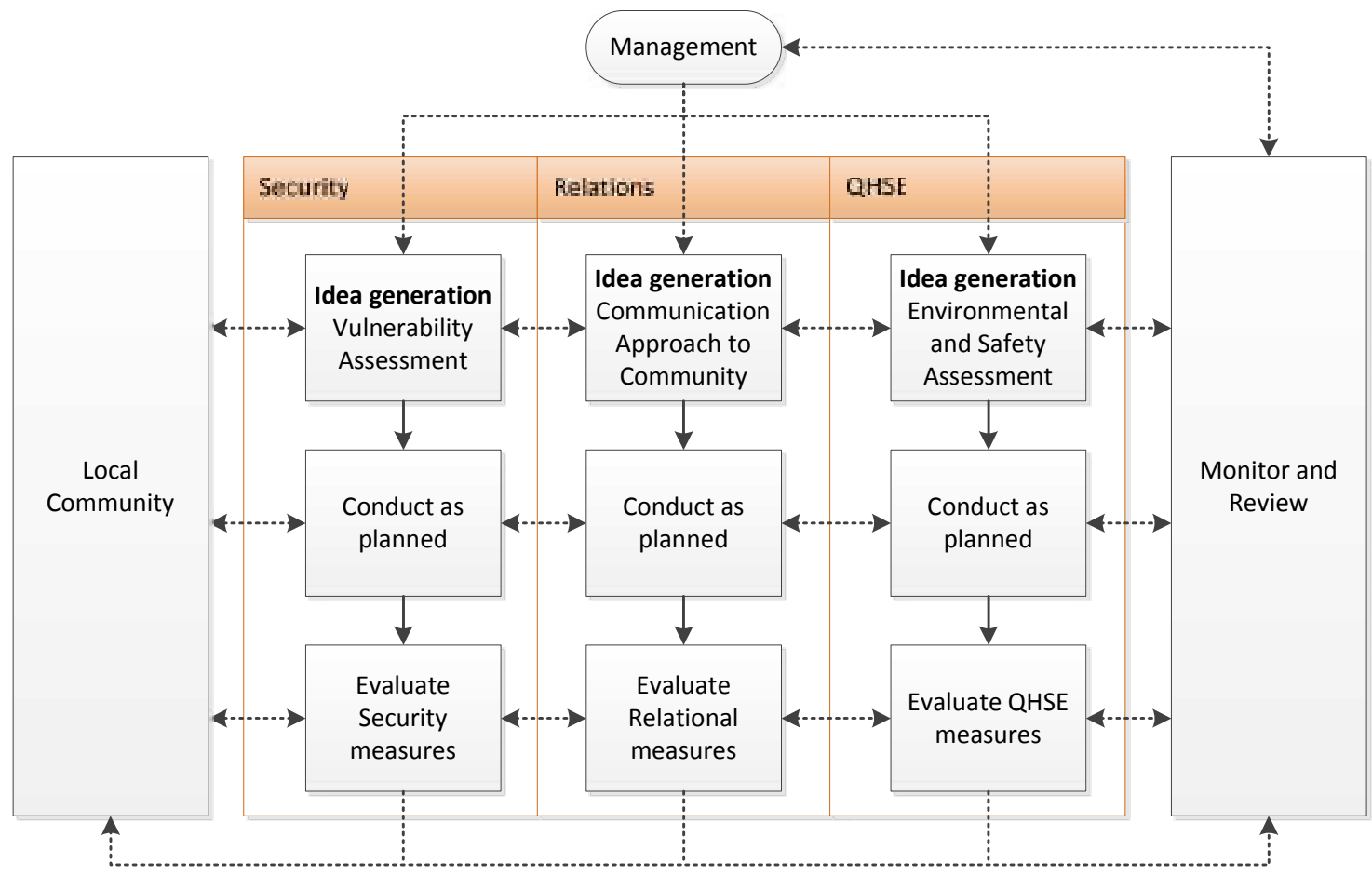

Fig. 9. Integrated Community Program Framework

Oil and gas Company must have sufficient human resources in engineering environmental aspects to support the safety concerns, along with substantial sustainability programs. Several alternatives to support the community-based security activities in the field of environmental aspect can be taken into account. One of the proposed activity by QHSE is fishaggregating-devices. Previous studies show that FADs are used for attracting and aggregating fishes towards an engineered floating object [16]. Generally, this can benefit also to the local fishermen to gather more fish around the FADs. Sustainable goals in terms of environment, and also people, can be achieved with this method. Environmentally, FADs can help the marine environment to recover from damaged, while this can also generate more income to the local fishermen around the area. These FADs can also be placed in the vulnerable areas where subsea cables are planted. Fishermen or local communities will be able to gather fishes from the FADs, while at the same time they can monitor the security conditions in the 
surrounding areas. This strategy can help the Company to obtain real-time information and protection in securing the Company's asset. Several FADs options can be discussed between Security and QHSE Department, to ensure that the needs of security protection and the environmental aspects can synergize and in the end support multi-department purposes.

\section{CONCLUSION}

From the above discussion, managerial implications can be concluded in a conceptual framework and submitted to the Management in the company in conducting and improving the community development program quality. As shown in Figure 9, Management must continuously monitor and review from the phase of idea generation conducted by the local community, Security Department, Relations Department, and QHSE Department. Three general steps shall be taken in conducting this program which are idea generation, implementation, and evaluation. As in every phases there will be difficulties, active involvement from Management is needed to minimize failure possibilities. Continuity is highly required in this activity, as this is not a one-time project only.

From the previous chapters and discussions, it can be concluded that the newly proposed approach of integrated comdev strategy can be one alternative to resolve the concerns in asset's security and sustainability as previously discussed in the observable results. This inter-departmental strategy can solve multiple aspects in security, environment, and relational issues. Inter-departmental approach, continuous monitoring and evaluation are the primary distinctions with the previous comdev approach which relies on single-department implementation, one-time project, and relatively low budget compared to the integrated approach. The new approach has significantly contributed improvement to Company's operations in the protection of subsea cable along with sustainability programs through community empowerment.

This study however has some limitations which focus on only one Company in the oil and gas industry, one area of operations, and limited three-months observable results that can be reported. However, this result can still provide powerful insights regarding the effectiveness of the integrated community development program. Future research is suggested to be carried out in multiple homogeneous industries, companies and multiple operation areas that have the same concern of possibility in protecting subsea cable through empowering and developing the community, with proactive effort to support sustainability. It is expected that further research in the field of subsea cable security and sustainability, could benefit not only to the Company, but also to the local communities around the area.

\section{REFERENCES}

[1] Reportase Bangka, "Dalang Pencurian Kabel Obtik Dibekuk Polisi," 13 February 2015. [Online]. Available: http://reportasebangka.com/berita/3169-dalang-pencurian-kabel-obtikdibekuk-polisi.

[2] "Kabel di Bawah Laut Dicuri, Pulau Kelapa Mati Listrik," 11 February 2016. [Online]. Available: http://megapolitan.kompas.com/read/2016/02/11/22343281/Kabel.di.Ba wah.Laut.Dicuri.Pulau.Kelapa.Mati.Listrik. [Accessed 19 May 2016].

[3] "Terungkap, Pencurian Kabel Bawah Laut Indosat," 26 June 2016. [Online]. Available: http://tekno.kompas.com/read/2013/06/26/15012294/Terungkap..Pencu rian.Kabel.Bawah.Laut.Indosat. [Accessed 19 May 2016].

[4] A. A. Setyanto, "Pencurian Kabel Laut Jaringan Internet Terungkap," 8 January 2015. [Online]. Available: http://www.tribunnews.com/regional/2015/01/08/pencurian-kabel-lautjaringan-internet-terungkap. [Accessed 19 May 2016].

[5] European Subsea Cable Association, "Submarine Power Cables," 2016.

[6] Abb.com, 2016.

[7] National Statistics Beaureau of Kepulauan Seribu, "Publikasi Kepulauan Seribu," 2014. [Online]. Available: http://kepulauanseribukab.bps.go.id/backend/tabelExcelIndo/Indo_23_ 1503774.xls. [Accessed 9 May 2016].

[8] Saferworld, "Community Based Approach to Safety and Security," 18 $\begin{array}{llll}\text { May } 2016 . & \text { [Online]. }\end{array}$ http://www.saferworld.org.uk/resources/view-resource/741community-based-approaches-to-safety-and-security. [Accessed 2016].

[9] Saferworld, "Community Based Approaches to Safety and Security: Lessons from Kosovo, Nepal and Bangladesh," London, 2013.

[10] C. P. M. Sianipar, G. Yudoko, A. Adhiutama and K. Dowaki, "Community empowerment through appropriate technology: sustaining the sustainable environment," Procedia Environmental Sciences, pp. 1007-1016, 2013.

[11] R. Yin, Case Study Research Design and Methods, Sage Publication, 1991.

[12] N. Khan, J. Ahmed, M. Nawaz and K. Zaman, "The Socio-Economic Determinants of Crime in Pakistan: New Evidence," Arab Economic and Business Journal, vol. 10, pp. 73-81, 2015. 